\title{
Compañeros de juego
}

\author{
Diana Beláustegui ${ }^{1}$
}

Cuando invitaba a sus amigos a jugar, su madre, una mujer gorda, propensa al mal humor, solía abrir la puerta y quedar parada ocupando todo el ancho de la abertura, con las piernas fofas llenas de várices abiertas y las manos en las caderas, observando.

Lucía hacía lo mismo, quedaba estática con la tacita de té en el aire o la muñeca a medio cambiar, mirándola, esperando alguna pregunta o un reto, tal vez una sugerencia como "bajá la voz", pero nada. Eso se repetía a menudo. Para terminar ese segmento tenso ella preguntaba: “¿sí, mamá?”. Y su madre la miraba un momento más antes de gruñir y entornar la puerta.

Cuando escuchaba que su progenitora regresaba a sus tareas habituales, se levantaba en silencio y cerraba la puerta.

Beláustegui, D. (2020). Compañeros de juego. Visitas al Patio, 14(2), 177-179. DOI: 10.32997/RVP-vol.14-num.2-2020-2788

Editor: Silvia Valero. Universidad de Cartagena-Colombia.

Copyright: (C 2020. Beláustegui, D. Este es un artículo de acceso abierto, distribuido bajo los términos de la licencia https://creativecommons.org/licenses/by-nc$\underline{\mathrm{sa} / 4.0 /}$ la cual permite el uso sin restricciones, distribución y reproducción en cualquier medio, siempre y cuando el original, el autor y la fuente sean acreditados.

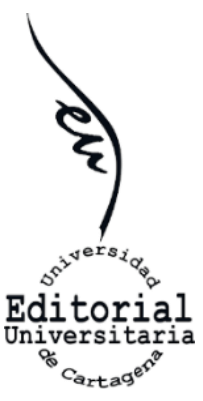

Visitas al Patio, 14(2), Diciembre/2020, p. 177-179
Lucía sonreía después de asegurarse que estaban solos y regresaba al juego como si nada hubiese pasado. En realidad, a los cinco años, nada dura lo suficiente como para arruinar el juego de la merienda o el de vestir a las muñecas para hacerlas modelar.

Los varones preferían sentarse en las esquinas y pasarse la pelota, haciéndola rodar por entre las piernas.

La regla para todos era: "silencio absoluto". La niña comprendía que sus amigos escapaban a la lógica de los adultos y que su madre podría quebrarse en dos tras un alarido si los descubría, pero ella los amaba y no le importaba qué pensaran los demás.

Se sentía acompañada: la cuidaban de noche. Cuando la distancia que su madre instauraba se hacía muy dura, estaban ellos para darle calor.

Era feliz con los niños.

Sentía que la familia estaba completa (aunque su progenitora ignorase que las presencias habitaban ahî).

Las mellizas "Lucía uno" y "Lucía dos" vivían entre el colchón y la cama. Ni bien la puerta se cerraba ellas aparecían por entre las sábanas, arrastrando sus cuerpos

\footnotetext{
${ }^{1}$ Diana Beláustegui (1974, Santiago del Estero) es una escritora argentina, dedicada prioritariamente a la narrativa. Ha colaborado con sus publicaciones en diversas revistas virtuales y blogs como Arte libertino, Tardes amarillas, Penumbria, Lengua de diablo y Scifi-terror. Su obra ha sido incorporada en numerosas antologías de circulación en Argentina y otros países: Argentina en versos y prosas (2006), 7 ma Antología anual especial de poesía y narrativa breve (2006), Escritura sin fronteras (2007), Argentina en versos y prosas (2009), El microrrelato en Santiago del Estero (2011), Antología jetona (2011), Summa colectivo de Arte (2012), Lo mejor de paracuentos (2013), Penumbria Año 1 (México, 2013), Picados. Antologia Lata peinada (2015), II Antologia Argonautas (Madrid, 2016), Nacer Hembra (2016). Tiene publicados dos libros de relatos, Escorpiones en las tripas (2014) y Cuentos inadaptados. La era de la destrucción (2018), y colaboró como guionista de dos historias incluidas como cómics en Viñetas del Estero 2 (2019).
} 
deformes, siempre dejando algún residuo amarillento en la tela del colchón. El poco espacio que las contenía las obligaba a replegarse demasiado entre ellas hasta fusionarse, apretando órganos, haciendo estallar algunas extrañas protuberancias que volvían a regenerarse mientras estaban afuera.

"Lucía tres" aparecía reptando desde atrás del ropero, masticando de vez en cuando alguna cucaracha, muchas veces cubierta la cara con telas de araña. Tenía un cuerpo prácticamente plano, con huesos diminutos y cristalizados, que sonaban y se quebraban produciendo miles de articulaciones cuando ella se movía. "Lucía tres" no tenía cabello, así que cada noche le robaba uno y se lo pegaba con saliva en la cabeza amorfa.

"Bruno uno" estaba en las paredes, siempre frío y con los ojos tristes. Él solía llorar siempre. A veces sin ningún motivo. Cuando ella le preguntaba qué le pasaba, él se limitaba a abrazar uno de sus brazos y hundir el rostro debajo de él.

La niña estaba tan acostumbrada a este ritual que a veces seguía jugando con "Bruno uno" metido en su axila.

"Bruno dos" vivía en el ropero, entre las sábanas blancas. El hambre era característico en él. Salía y mordía las paredes, descascarándolas. Lucía, la niña viva, lo metía detrás del televisor para que se alimentara tranquilo sin que su madre descubriera la pared agujereada. El niño no tenía dientes, sólo unas encías lustrosas y fuertes, rara vez sangraban, muchas veces se hinchaban y reventaban con pus, pero rara vez sangraban.

Le tenían un miedo absurdo a la mujer gorda y cuando sentían que se acercaba, prácticamente desaparecían en sus escondites. Una vez Bruno, el del ropero, vomitó ectoplasma verde luego de ser casi descubierto.

-Ella no es mala- les aclaraba Lucía viva.

-Parece que ya no, ahora que está vieja se ha calmado un poco-comentó de pasada, una tarde, "Lucía tres".

Y la niña no supo lo que su amiga había querido decir, pero prefería no preguntar y jugaba a sentarse frente al espejo para que las mellizas la peinaran, y casi siempre se quedaba perpleja ante el asombroso parecido que tenían con ella misma. Pero una niña de cinco años no lo relaciona con algo genético, simplemente se maravilla y queda feliz con las casualidades.

Todos tenían semejanzas que aparecían, a pesar de sus malformaciones.

En agosto la mujer gorda comenzó a engordar más y a ponerse violenta. Sin la menor provocación estallaba en ruidosos enojos.

Los niños que vivían en los recovecos de la habitación fueron los primeros en sospechar que la madre de la niña estaba otra vez embarazada e hicieron apuestas sobre cuál sería el lugar de Lucía viva. Secretamente se alegraron cuando vieron entrar a la gorda a la habitación mientras la niña dormía, con un martillo grandote, de esos que usan en las carnicerías para machacar la carne. 
A veces sentían celos de su hermana, ellos no habían durado tanto.

No salieron de sus escondites, pero sí hicieron rodar los ojos como pelotitas viejas y amorfas, por sobre el suelo para poder espiar de cerca la matanza.

Ya por experiencia sabían que cuando uno se gestaba en la panza, el que vivía en la casa, sobraba.

Cuando Lucía viva, ahora "Lucía cuatro", apareció de nuevo a jugar con la cabeza abierta como en un grotesco abanico, eligió su lugar. Se quedó a vivir en la tacita de té, que estaba sobre la mesita principal, al lado de la cuna que sería ocupada en unos cuantos meses más por la nueva Lucía o Bruno vivo.

(De Cuentos inadaptados. La era de la destrucción) 